\title{
AN EXPLORATORY STUDY OF THE RHETORIC IN CSR REPORTS: A COMPARISON OF SHARI'AH COMPLIANT COMPANY AND NON -SHARI'AH COMPLIANT COMPANY IN MALAYSIA
}

\author{
Rafizan Abdul Razak \\ Universiti Teknologi MARA, Cawangan Negeri Sembilan
}

\begin{abstract}
This paper advances previous research in corporate social reporting (CSR) by using a taxonomy of five distinct rhetorical strategies to examine any differences in term of type of ethical categories and to identify moral attitudes towards different societal activities between Shari'ah compliant company Bank Islam Malaysia Berhad (BIMB) and Non-Shari'ah compliant company Malayan Banking Berhad (Maybank). The data is analyzed using content analysis. The findings revealed that there are different rhetoric applied in both types of companies such as Agency (profit), Benefit (collective welfare), Compliance (law and contracts), Duty and Ethos (virtue). In term of moral attitudes, both types of companies disclosed relatively similar behaviour and commitment towards CSR. This research is the first of its kind to be conducted in Malaysia by using this new approach and will contribute new insights to existing CSR literatures in Malaysia.
\end{abstract}

Keywords: Agency, Benefit, Compliance, Duty and Ethos.

\section{INTRODUCTION}

Ethics and corporate social responsibility are related to each other in many ways. The behaviour of companies in constantly disclosing their social responsibility shows that they are morally responsible and ethical companies. The stakeholders and the public will normally give preferences and trust to those companies that they perceived as having a good behaviour and/or conduct.

Yunanda and Abd. Majid (2011) highlighted that the erosion of trust by the business's stakeholders is mainly due to the immoral bahaviour of the business's administrators ranging from chief executive officers to lower level managers and its employees. Such act may tarnish the status of the company and subject to lawful approval.

On the other hand, Ditlev-Simonsen and Wenstop (2011) highlighted different dimension on corporate social disclosure research by looking at what ethical perspectives corporation actually had applied in the companies' corporate social responsibility (CSR) report rhetoric. In their study, they developed a taxonomy of rhetorical strategies which consist of five areas.

\footnotetext{
*Corresponding author's email: rafizanabdulrazak@gmail.com
} 
The taxonomy is used for describing the purpose of CSR and it consist of Agency (profit), Benefit (collective welfare), Compliance (law and contracts), Duty and Ethos (virtue). Their result had shown that different rhetoric is applied in companies' report where ethos had been the most common ethical perspective expressed in the report. ${ }^{\dagger}$

In Malaysia, the CSR study focuses on the nature, status or trend, quality, quantity and factors of disclosure in both Non- Shari'ah - compliant and the Shari'ah compliant companies' annual reports (Anuar et.al., 2004, Yahya et al., 2005, Amran and Devi,2008; Said et al., 2009; Mohamad et al., 2010 ; Esa and Ghazali., 2012). However, none has been noted to have discussed the type of ethical categories and moral attitude of company in divulging CSR in the annual report. Therefore, by using the taxonomy of rhetorical strategies framework, this study intends to examine the following two research questions:

1. Are there any differences in terms of the type of ethical categories between Shari'ah compliant and Non-Shari'ah compliant companies in Malaysia?

2. To identify any differences in terms of moral attitudes towards different societal activities between Shari'ah compliant and Non-Shari'ah compliant companies in Malaysia.

Thus, this study seeks to contribute to the literatures by reviewing and documenting CSR reporting on the area concerned in Malaysia. The present study will also extend the literatures on CSR in relation to Shari'ah compliant companies as no recent studies in the area have been published in Malaysia. A comparison between Shari'ah compliant and Non-Shari'ah compliant companies would be a meaningful contribution given the fact that in depth studies on this area are limited.

\section{LITERATURE REVIEW}

\section{SHARI'AH COMPLIANT AND NON-SHARI'AH COMPLIANT COMPANIES}

In Malaysia, the Securities Commission (SC) was established on 1 March 1993 under the Securities Commission Act 1993 to regulate the capital market. In 1996, the SC has set up Syariah Advisory Council (SAC) to provide requirement of specific investors to invest in capital market that abides with Shariah rules and principles. According to Ousama and Fatima (2010) the SAC applies standard criteria in classifying the companies listed in Bursa Malaysia as approved and non-approved companies based on their core activities. Companies with major activities which are not conflicting to the Shariah principles are categorized as Shari'ah compliant whereas Non-Shari'ah compliant are companies involved in primary activities deemed not lawful according to the Shariah.

\section{ETHICS AND CSR}

There were many definitions of ethics which had been stated in previous literatures (Freeman and Gilbert, 1988; Raiborn and Payne, 1990; Carroll, 1991). Brenda and Payne (2002) stated that the definitions of ethics and morality are cross-referenced to each other. According to De George (1999) as cited in Brenda and Payne (2002), he defined business ethics as the interaction of ethics and business. Such a definition encompasses a moral evaluation of the 
economic system of the free enterprise system in the United States, the businesses which operate in this system, a moral evaluation of individuals and their actions in conducting business and a review of business behavior in the international arena. De George provides further illumination: moral judgements should be universally applicable, they involved serious matters with potential to cause serious results, and moral judgements invoked praise or blame. Additionally, moral judgements can only be made by individuals for themselves: others, including governmental agencies, cannot forced moral judgements on anyone.

Brenda and Payne (2002) stated that businesses will in fact engage in ethical business practices for one of two reasons, one ethical in nature and the other one is for more Machiavellian. The ethical motivation guiding business is related to a desire to do the right thing, without external pressure or governmental constraint. Furthermore, Brenda and Payne (2002) highlighted that the more Machiavellian approach that businesses espouse in their use of ethics has its roots in a desire to convince the stakeholder that the firm is doing the right thing.

On the other hand, according to Carroll (1979) as cited in Dusuki and Tengku Mohd Yusof (2008), the definition of CSR is too wide in that it encompasses economic, legal and voluntary activities. Carroll (1979: 500) defines CSR as "the social responsibility of business encompasses the economic, legal, ethical, and discretionary expectations that society has of organizations at a given point in time". In order for the business to fully address their obligation to society, all these four categories of expectation on the economic, legal, and ethical and philanthropy (discretionary) must be met.

Therefore, we can assert that a company's action is influenced by the desire to evade legal consequences of its actions or to persuade the stakeholders that the company does have their best interests at humanity and seeks to assist their interests rather than their own. This is where we can normally see in companies' annual report under their CSR's section or standalone sustainability report.

\section{ETHICS RHETORIC IN CSR REPORTING}

Ditlev-Simonsen and Wenstop (2011) defined rhetoric as the art of using language to communicate effectively which is applied to convey message. They anticipated corporation presumptively apply ethics rhetoric in their CSR reports to achieve certain communication goal such as enhancing legitimacy. Furthermore, Ditlev-Simonsen and Wenstop (2011) emphasized that the ethical attitude behind a company's CSR is presumably a determining element for its CSR activities and a relevant place to look for the expression of such attitudes is the rhetoric applied in CSR reports. Therefore, this study is conducted to fill the gap in this area in Malaysia.

\section{DATA COLLECTION AND METHODOLOGY}

This study focused on disclosure made in two corporate annual reports. Since this is an exploratory study and due to time constraint, the author focused on Bank Islam Malaysia Berhad (BIMB) to represent Shari'ah compliant company and Malayan Banking Berhad (Maybank) to represent Non-Shari'ah compliant company to make the comparisons. BIMB was selected as a subject because it is the first Islamic bank established in Malaysia and is based on Shari'ah principle. On the other hand, Maybank was selected because the company had won one of the NACRA awards for year 2014. This study embraced the taxonomy of ethics rhetoric applied in Ditlev-Simonsen and Wenstop (2011) which consists of five 
categories to classify the rhetoric strategies revealed in the two annual reports. The following section will describe the definition of five rhetoric strategies.

\section{AGENCY}

Ditlev-Simonsen and Wenstop (2011) described agency in their study as a criteria that linked to the ethical perspective of egoism. However, they looked at wider perspective than individual level of egoism. In their taxonomy, agency is an extension of egoism. According to Ditlev- Simonsen and Wenstop (2011), for example, in a typical business organization, the motives of its owners by extension also become the motives of the agents employed to work on the organization. Therefore, in this study the author used the same notion to identify the ethical commitment made by BIMB and Maybank.

\section{BENEFIT}

Ditlev-Simonsen and Wenstop (2011) described benefit as a criteria that linked to benevolent consequentialism and utilitarianism. It expressed a commitment to further interests, welfare or well-being of stakeholders outside the boundaries of the firm. Thus, in this study the author is interested to compare how Shari'ah and Non- Shari'ah companies expressed their concerns to customers and social good and the environment.

\section{CONTRACT}

According to Ditlev-Simonsen and Wenstop (2011) contract is a criterion that linked to contractualism where it can be thought as either actual or ideal. For instance, organization will follow existing rules and regulations and not go beyond what is required from them. Therefore, in this study the author would like to know how Shari'ah and Non- Shari'ah companies are different from each other.

\section{DUTY}

Next, Ditlev-Simonsen and Wenstop (2011) described duty as criteria relates to ethical duty. They further conferred that there are certain things that organization should engaged in which is independent of laws and regulations. In other words, the organization should have embarked into certain things as other organization did. Hence, in this study the author is concerned about the similarities between Shari'ah and Non- Shari'ah companies as well as their differences.

\section{ETHOS}

Lastly, Ditlev-Simonsen and Wenstop (2011) defined ethos as criteria that expressed a commitment to virtues or to avoid, (how one would want to be as opposed to look at what to do). According to them, ethos needs to be separated out as distinct rhetoric strategy because it communicates a distinctive sort of moral commitment. In this study, the author intends to highlight which company used its CSR reporting to express their moral commitment in most extensive manner. 


\section{METHODOLOGY}

\section{SELECTION OF QUOTES AND INTERPRETATION}

The annual reports of BIMB and Maybank were read thoroughly to identify the social responsibility disclosure. Similar with Rahman et.al (2010), this study used a number of CSR sentences to identify ethical commitment. Milne and Adler (1999) conferred that using sentences for coding and measurement would provide complete, reliable and meaningful data for further analysis. Therefore, the number of sentences was chosen to classify ethical rhetoric. Then, the quotes were assigned and grouped to ethical categories based on a checklist of disclosure item designed by Ditlev-Simonsen and Wenstop (2011) above.

Once the sentences or paragraph were group to ethical categories, we also identify the moral attitudes as to why the company disclosed it. As stated in Ditlev-Simonsen and Wenstop (2011) one company may emphasize a commitment to benefit, but also state that it is doing so in order to meet a commitment to agency. They further elaborated that the end motive here is agency and the pattern of moral reasoning is that benefit is an instrument for agency.

\section{FINDINGS}

The following discussion encompasses the result of the study.

\section{AGENCY}

Both companies disclosed their CSR activities related to agency strategies. This is anticipated as the general objective of doing business is to make profit. Apart from focusing on the bottom line, both companies do cognizant about sustainability of their organization operation and activities as can be seen from their involvement and commitment in CSR. The followings are the quotes on agency strategy in BIMB:

"The core of the Bank's corporate social responsibility programme is driven by Shariah principles that pertain to uplifting the lives of destitute and poor Muslims through the contribution of Zakat, or obligatory alms. As our business revenue and profit grow, so does our Zakat contribution. In 2014, the Bank's Zakat contribution exceeded RM1 2 million. A significant portion of this was channeled to fund vital social causes across Malaysia with emphasis on poverty reduction projects, education initiatives, health and welfare support and unity programmes".

(BIMB Annual report 2014, page 28) It is clear that BIMB emphasised on the welfare of the community and their obligation as Shari'ah compliant company to share the business income. This is coherent with the Tawhid concept as stated in Yunanda at el (2011) where believing in one and the only God is the paramount essence of Islam. This leads to the conformity of Qur'anic ordinances and Sunnah as the primary rules and man-made rules in particular. The above statement also emphasis that as a Shari'ah compliant company, BIMB moral attitude is driven by their responsibility for distribution of wealth and financial interest as a secondary objective.

On the other hand, the following is the quote pertaining to the agency strategy in Maybank:

"Our sustainability progress is in line with our mission to humanise financial services. In 2014, the Board-approved 20/20 Sustainability Plan took effect with the objective of 
implementing an impact-based approach focused on environment, social and governance (ESG) issues. Through the 20/20 Sustainability Plan, we aim to align our sustainability progress with our corporate strategy in order to achieve holistic growth for all of our stakeholders. We want to create enduring meaning and value across the workplace, marketplace, environment and community in ways that are globally significant and yet locally relevant. The achievement of these goals and the realisation of our value proposition contribute to our business competitiveness and are significant to maintaining our social licence to operate. As the region's leading financial institution and to prepare our business for the future, we have to embed sustainability into our operations and conduct our business in away that creates value for our stakeholders over the short and long term. We also have the responsibility to manage our impacts positively".

(Maybank Annual report 2014, page 46)

Similar with BIMB, Maybank's attention on CSR effort can be seen on their 20/20 Sustainability Plan. However, as a Non-Shari'ah compliant company, the motives behind their CSR activities is more on business ethics in general or doing what is right. NonShari'ah compliant company perceived that in achieving their business goal, they do belief towards portraying the social contribution activities to be accepted in community and industry.

\section{BENEFIT}

The next taxonomy is benefit. From the analysis, we found that both companies disclosed the information about how they are focusing on their benevolents to the stakeholders, environment and community in which they operate.

The following quotes were reported in BIMB:

"The development of future talent for the industry is a core concern of the Bank. Towards this end, the Bank has launched a number of Human Resource initiatives targeting the development of its own 4,242 strong workforce as well as supported government launched programmes to help groom the potential of fresh graduates; namely Skim Latihan 1Malaysia ("SL1M") and the Graduate Employability Management Scheme ("GEMS")".

(BIMB Annual report 2014, page 30)

"The best workplace produces a productive workforce who work towards one goal in unison. In building an effective team who are driven by a common purpose with individual measurable goals, the Bank understands that good management, clear communication and building trust and rapport through a two-way communication is necessary. Employee engagement activities outside the workplace accelerate this strengthening of comradeship. In 2014, activities aimed at promoting healthy lifestyles and building team spirit amongst the employees continue to take centre stage. The HR Division co-organised the Bank Islam Sports Carnival 2014 in Kuching, Sarawak, Bank Islam's Health Day and other sports activities such as the National Banks Sports Council Futsal Tournament, National Banks Sports Council Carrom Tournament and Futsal Challenge, Piala Dato' Sri Zukri. Hari Raya and Buka Puasa gatherings also continued to provide occasions to gather in positive spirit."

(BIMB Annual report 2014, page 150)

The above report revealed that BIMB focused more on development of human capital within the industry as well as the nation too. At the same time BIMB also recognized healthy lifestyles among their employees. 
On the other hand, the following quotes were highlighted by Maybank:

\section{"People}

We are constantly working towards providing our people with the tools and support in order for them to perform better. In 2014, we created an inclusive working environment through various employee engagement programmes, employee training programmes as well as rewarding our people fairly for their work.

Access to service and product

We are committed to having deep knowledge of our clients, including understanding their social and environmental needs. At the same time, we believe that our business will only thrive when embedded with elements of good governance, social innovation and environmental integrity. Our efforts to-date were made to enhance our services by improving the accessibility and convenience for our customers and to make valuable contributions to the communities where we operate.

\section{Focus on Customers}

In 2014, we continued on our mission to humanise financial services regionally with the launch of various products and services aimed at our improving the accessibility and efficiency of our services, reaching out to the financially underserved, and expanding our physical and digital footprint without compromising the security of our customers' data and information.

\section{Access to Finance}

As a financial institution, our services provide access to finance that spreads across Asia. We have one of the widest networks in Malaysia and the only bank with branches in 18 rural areas in the country. 16 of our branches in Malaysia are disabled-friendly whilst all 55 Maybank branches in the Philippines are catered to people with disabilities.

\section{Product Stewardship}

Our commitment to enhance access to financing for all levels of SMEs was reflected in the Portfolio Guarantee (PG) agreement with the Credit Guarantee Corporation (CGC). A sum of RM1 billion was set aside to provide financing to viable SMEs under the PG schemes, a portion of which will be allocated to the Bumiputera segment, thus making it the largest agreement of its kind to be inked between CGC and any financial institution in Malaysia. We provided further support to SMEs by partnering the Bumiputera Agenda Steering Unit (TERAJU) to provide RM600 million funding to high-performing Bumiputera SMEs. This partnership expanded the Teras Fund to RM2.2 billion. This fund, created by TERAJU, will assist SMEs to obtain working capital to grow their businesses".

(Maybank Annual report 2014, page 204-205)

We can see that there were no differences between Shari'ah compliant and Non-Shari'ah compliant companies in terms of their involvements and roles in giving back to the stakeholders and the society. The only difference is in terms of presentation of the strategies 
whereby Maybank has remarked their commitments in a more comprehensive and structured manner compared to BIMB. In terms of expression, it has shown that Maybank's reports are more enlightened in winning the heart of the reader. Form the above paragraph, the benefit instrument also act as commitment to achieve agency commitment. In addition, in terms of moral attitude, there were no differences Shari'ah compliant and Non-Shari'ah compliant companies. Both type of companies expressed the same attitude to take a good care of their stakeholders.

\section{CONTRACT}

The next taxonomy is contract. The BIMB report has articulated a contract commitment which is bound by the bank to ensure fair and proper distribution of Zakat funds to those who need it (Asnaf). This is consistent with research done by Abdul Rahman, Mohd. Hashim and Abu Bakar (2010) which indicated that Zakat obligations and Sha'riah Supervisory Council (SSC) were disclosed in BIMB reports from year 1992 to 2005. This is due to the fact that payment pertaining to Zakat matters, reports and attestation of SSC, as well as the investment account, are required to be disclosed by paragraphs 71 and 72 of the FRS i-1.

The following quotes were reported in BIMB:

\section{CAPTURING THE SPIRIT OF SOCIAL DEVELOPMENT}

“As Malaysia's leading Islamic financial institution, many of our CR efforts are underpinned by Zakat contributions. In line with Islamic principles and laws, it is our utmost priority to ensure fair and proper distribution of Zakat funds for a variety of noble causes and to contribute to the nation's social development. Bank Islam remains the leading corporation in Malaysia in developing and organising Zakat-funded CR projects, playing an important role in disseminating this wealth among the community.

As Bank Islam's asset and performance continue to grow, so has our Zakat fund increased to support our CR initiatives. Our spending over the years in helping to build better lives for those who truly need it is a reflection of Bank Islam's commitment to promote social justice and foster a sense of solidarity in society."

(BIMB Annual report 2014, page 131)

The above statement also highlighted the moral attitude of Shari'ah company that is tied with Islamic principles and laws. This is consistent with research done by Wan Abdullah, Percy and Stewart (2013). On the other hand, in Non-Shari'ah compliant company their contract is linked with the growth and stability of the company in the present and future. The company will look for the opportunity to portray a good business model to environment in which they operate.

The following is the quote pertaining to the contract strategy in Maybank:

\footnotetext{
"Sustainability at Maybank means conducting business in a way that enhances performance responsibly - today and over the long-term. We continue to serve ASEAN communities while strengthening and expanding our operations regionally. Our sustainability journey is a reflection of Maybank's position as a regional leader in the provision of financial services and one that supports business growth through impact based approaches."
} 
(Maybank Annual report 2014, page 198)

\section{DUTY}

Next taxonomy is related to duty. The reports in BIMB and Maybank focused on community and human capital development. Both Shari'ah and Non-Shari'ah compliant companies engaged in many activities that show their concerned and responsibility to fulfil the need of people in which the business operate.

The following are the quotes reported in BIMB:

"Since 2008, our Housing Aid Project has been helping to provide a roof over the heads of those suffering from extreme poverty. We believe that this effort is pivotal not only in providing a basic necessity to those in need, but also in enabling them to gain independence to improve their livelihoods.

The holy month of Ramadan is a time of giving and sharing. While Bank Islam continuously strives to foster the spirit of goodwill throughout the year, the fasting month provides us with an opportunity to intensify our CR efforts to improve the well-being of the communities we operate in.

Bank Islam's affiliation with the PINTAR Foundation in its School Adoption Programme has made it possible for us to organise motivational programmes with the Malaysian army, as part of our efforts in educating and imparting useful skills to the primary school students.

As part of our commitment to the environment in helping create a sustainable future, Bank Islam looked to the ecological paradise that is Sabah in launching its "One Earth, One Quest - Mangroves, Our Priceless Treasure" campaign. By making a contribution of RM50,000 to Sabah Wetlands Conservation Society, we participated in the mangrove trees re-planting effort".

(BIMB Annual report 2014, page 131-136)

The following are the quotes reported in Maybank:

"Since its inception in 1972, Maybank has sponsored more than 1,000 scholars as well as provided them with employment opportunities. Driving education at all levels will enable us to build human capital throughout the region where we operate. Maybank Foundation also offered scholarships to 33 students in Indonesia to pursue their tertiary education in Indonesia, Malaysia and Singapore. The regionalisation of our scholarship awards will be a key driver in our support of educational programmes moving forward.

Under our schools adoption programme, PEERS, we commit to improve the standard of education in rural schools through academic support as well as personal development and capacity building. Together with selected partners, we adopted 15 schools in three areas under the PEERS programme, rewarding achievements, providing ICT facilities as well as promoting language proficiency in English. ICT.

\section{CashUP Programme}


The programme aims to encourage low-income families to cultivate the habit of saving money. The CashUp programme provides 1 to 1 ratio matching payment to participating families which essentially doubles their savings.

\section{Maybank Family Protection Programme}

The programme has benefited 600 families, insuring the breadwinners of the family by covering work related accidents and injuries. The targeted beneficiaries were chosen from families with total household income of less than RM5,000”.

(Maybank Annual report 2014, page 200-201)

From the above reports also, we found that there were similarities in term of moral attitudes between Shari'ah and Non-Shari'ah compliant companies that driven their reporting.

\section{ETHOS}

The last ethical strategy is ethos as to how the company would like to be seen by the industry or community. This strategy includes any action taken and long term commitment showed by the companies to contribute to the society in general and how the companies ensure their sustainability.

The following are the quotes reported in BIMB:

"As Malaysia's pioneer Islamic bank, Bank Islam has established a rich history of giving back to the community and environment. In adherence to the Shariah principles that shape the Bank's business, responsible corporate practices make up the very essence of the Bank's operations. With the aim of ensuring the sustainability of our business and long-term wellbeing of those around us, our Corporate Responsibility ("CR") practices are thus geared not only towards preserving the bank's legacy, but also towards securing its future, and the future of the communities we serve, for years to come. We also seek to cement this sustainability through our efforts to adapt to society's evolving needs and contribute to the overall wellness of local communities.

To this end, our CR programmes focus on creating long-term value for underprivileged communities through education, welfare and enrichment initiatives to help them attain a brighter tomorrow. At the same time, we stand ready to channel financial and medical aid to those who need it the most. We are also firm believers in volunteerism, encouraging our staff and their families to engage with the less fortunate and contribute to the betterment of their quality of life".

(BIMB Annual report 2014, page 130)

From the above, it is reported that BIMB as a pioneer in Islamic bank in Malaysia will continue their legacy as a leading in Shari'ah compliant companies. Therefore, from the report we can see the link between duty and ethos whereby BIMB's commitment in fulfilling its duty would also help them in realizing ethos.

Followings are the quotes reported in Maybank:

"The three pillars serve as a guide in our efforts to achieve the targets set and move purposefully towards the ten commitments which we began tracking in 2015. The ten 
commitments, which are to be implemented by different departments, promote Maybank's sustainability focus that cuts across the three pillars.

\section{The 20/20 Sustainability Plan}

People: To build the most engaged and inclusive workplace to help us connect with customers and make better, more informed decisions for our business.

Community and Citizenship: To deliver long-term value for the community and environment by being the region's most impactful corporate citizen.

Access to Products and Services: We plan to integrate ESG considerations into our products and services by 2020 to practise responsible financing, promote financial inclusion and help our customers build financial capability".

(Maybank Annual report 2014, page 198-215)

"In 2014, we continued with the mission to humanise financial services by implementing activities and high-impact initiatives in our efforts to uplift the lives and wellbeing of underprivileged Malaysians, which has brought the bank closer to the community in many ways".

(Maybank Annual report 2014, page 154)

Maybank on the other hand, had showed their exertion through long term vision as highlighted above. The company had a very clear direction and focused group. All engagement activities in CSR in the company basically will comprehend the 20/20 Sustainability Plan aka ethos.

\section{CONCLUSION}

This study has been conducted to classify the type of ethical categories between Shari'ah compliant and Non-Shari'ah compliant companies in Malaysia and to identify any differences in terms of moral attitudes towards different societal activities between Shari'ah compliant and Non-Shari'ah compliant companies in Malaysia. We used the taxonomy of ethics rhetoric applied in Ditlev-Simonsen and Wenstop (2011) which consists of five categories to classify the rhetoric strategies revealed in the two annual reports which were BIMB and Maybank. From the above discussion, both companies expressed their CSR reporting in all five categories of the ethical strategies which are Agency, Benefit, Contract, Duty and Ethos. Since CSR disclosures are voluntary in nature, both companies are freely to communicate any types of rhetoric ethical categories.

However, in term of moral attitudes, BIMB, as Shari'ah compliant company are bound to Islamic principles and laws. Therefore, any activities conducted by the BIMB in relation to business matter or CSR initiatives are tied to Qur'anic ordinances and Sunnah. For instance, in this study the Agency and Contract ethical strategies reported in BIMB are clearly rely on Shari'ah principles. On the other hand, Maybank as Non-Shari'ah compliant company concerned on making profit as the first priority and doing good for society at the same time.

The limitation of this study lies in the data. Due to the limited financing and time this study only used two annual reports. One to represent Shari'ah compliant company and the other one for Non- Shari'ah compliant company. Nevertheless, even with this limitation, the contribution is found to be significant knowing that such CSR study using the taxonomy of 
five rhetoric ethical strategies is still new in Malaysia. Future study can be conducted by using larger sample and industry.

\section{REFERENCES}

Abdul Rahman, A., Mohd. Hashim, M.F.A., and Abu Bakar,F. (2010) "Corporate social reporting: a preliminary study of Bank Islam Malaysia Berhad (BIMB)", Issues in Social and Environmental Accounting, Vol. 4, No. 1 June 2010, pp. 18-39.

Amran, A. and Devi, S.S. (2008) "The impact of government and foreign affiliate influence on corporate social reporting: the case of Malaysia", Managerial Auditing Journal, Vol.23, No.4, pp. 386-404.

Anuar, H.,Sulaiman, M. and Ahmad,N. (2004) "Environmental reporting of Shari'ah approved companies in Malaysia", Proceeding of International Accounting Conference II, International Islamic University, Kuala Lumpur.

Bank Islam Malaysia Berhad (BIMB) Annual report 2014.

Brenda E. Joyner and Payne, D. (2002) "Evolution and Implementation: A study of values, business ethics and corporate social responsibility", Journal of Business Ethics, 41, pp. 297-311.

Carroll, A. B. (1991) "The Pyramid of Corporate Social Responsibility - Toward the Moral Management of Organizational Stakeholders", Business Horizons, 34, 4: pp. 39-48.

Ditlev-Simonsen.C.D. and Wenstop, S. (2011) "Companies' ethical commitment-an analysis of the rhetoric in CSR reports", Issues in Social and Environmental Accounting, Vol.5, No1/2 December 2011, pp. 65-81.

Dusuki, A.W and Tengku Mohd Yusof, T.F.M. (2008) "The pyramid of corporate social responsibility model: empirical evidence from Malaysian stakeholder perspectives", Malaysian Accounting Review, Volume 7, No. 2, pp29-54.

Esa, E. and Mohd. Ghazali, N.A. (2012) "Corporate social responsibility and corporate governance in Malaysian government-linked companies", Corporate Governance, Vol. 12, No.3, pp. 292-305.

Freeman, R. E. and D. E. Gilbert Jr. (1988) "Corporate strategy and the search for ethics", Prentice Hall, Englewood Cliffs, NJ.

List of Shariah-Compliant Securities by the Shariah Advisory Council of the Securities Commission Malaysia.

Malayan Banking Berhad (Maybank) Annual Report 2014.

Milne, M.J. and Adler,R.W. (1999) "Exploring the reliability of social and environmental disclosures content analysis", Accounting, Auditing \& Accountability Journal, Vol. 12 Iss: 2 , pp. $237-256$. 
Mohamad, R., Alwi, K. and Jamil, C.Z.M. (2010) "Sustainability disclosure among Malaysia Shari'ah- Compliant listed companies: Web reporting", Issues in Social and Environmental Accounting, Vol. 3, No. 2, pp. 160-179.

Ousama, A.A. and Fatima, A.H. (2010) "Factors influencing voluntary disclosure: empirical evidence from Shariah approved companies", Malaysia Accounting Reviews, Vol.9, No. 1, pp. 85-103.

Raiborn, C.A. and Payne, D. (1990) "Corporate codes of conduct: a collective conscience and continuum”, Journal of Business Ethics 9, pp. 897-889.

Said, R., Zainuddin, Y.H. and Haron, H. (2009) "The relationship between corporate social disclosure and corporate governance characteristics in Malaysian public listed companies", Social Responsibility Journal, Vol.5, No.2, pp. 212-226.

Yahya, M.A., Abul Rahman, A. and Tayib, M. (2005) "The relationship between corporate social disclosure and Islamic unit trust shareholding", Accounting, Commerce and Finance: The Islamic Perspective Journal, Vol.9, No. 1, pp. 95-63.

Yunanda,R.A and Abd. Majid, N. (2011) "The contribution of Islamic ethics towards ethical accounting practices", Issues in Social and Environmental Accounting, Vol. 5, No. 1/2 , pp. 124-137.

Wan Abdullah, W.A., Percy, M. and Stewart, J. (2013) "Shari'ah disclosures in Malaysia and Indonesian Islamic Bank", Journal of Islamic Accounting and Business Research, Vol.4, No.2, pp. 100-131. 